\title{
THE EFFECT OF MICROSTRUCTURE ON THE SCC BEHAVIOR OF ALLOY 718
}

\author{
I.L.W. Wilson and M.G. Burke \\ Westinghouse Electric Corporation \\ Pittsburgh. PA. 15235
}

\begin{abstract}
The susceptibility of thermally treated Alloy 718 to stress corrosion cracking (SCC) has been evaluated in simulated pressurized and boiling water reactor environments. In order to determine the microstructural feature(s) which are associated with SCC susceptibility, a detailed characterization of the thermally treated materials has been performed using analytical electron microscopy. A correlation was observed between the presence of Laves phase in the microstructure and the SCC performance of the alloy.
\end{abstract}




\section{INTRODUCTION}

Alloy 718 is a high strength, precipitation-hardened Ni-based alloy which has been used for certain critical applications in nuclear reactors. The heat treatments which had previously been used for Alloy 718 were based upon those which had been developed for aerospace applications rather than light water reactor service. In reactor service applications, Alloy 718 has provided good service, and incidents have not seriously affected reactor operation [1]. Available laboratory data, however, indicate that Alloy 718 is resistant to stress corrosion crack (SCC) initiation, but that relatively small defects could lead to rapid crack growth [2-4]. No major variation in cracking behavior with heat treatment has yet been observed [3-5], but no systematic study has been performed to date. Corrosion fatigue data, however, have suggested that significant improvements in performance could be gained by employing heat treatments that avoid the precipitation of Laves phase at the grain boundaries [6]. Moreover, recent combined AEM/APFIM studies have clarified the detailed chemistries of the component phases, thereby facilitating the development of optimized microstructures via controlled thermal treatments $[7,8]$.

This study, funded by the Electric Power Research Institute, was conducted to determine if increased resistance to crack growth could be obtained in Alloy 718 while maintaining its resistance to crack initiation through the use of various thermal treatments.

\section{EXPERIMENTAL}

The composition of the Alloy 718 used for this investigation is listed in Table I. The solution heat treatment of $1038^{\circ} \mathrm{C}$ for $1 \mathrm{~h}$ was selected based upon optical microscopy examination of the material which showed that this temperature was sufficient to dissolve most second phase particles without promoting excessive grain growth. Aging treatments, subsequent to the solution heat treatment, were systematically selected to produce a range of $\gamma^{\prime \prime}, \gamma^{\prime}, \delta$, and Laves phase structures within the $\gamma$ matrix. The major variation in the heat treatments involved an intermediate aging step at either $982^{\circ} \mathrm{C}$ or $871^{\circ} \mathrm{C}$. The individual aging treatments are detailed in Table II. The measured hardness values of the heat-treated samples are also included in Table II.

TABLE I

COMPOSITION OF ALLOY 718 (wt.\%)

\begin{tabular}{ccccccccccc}
\hline $\mathrm{Ni}$ & $\mathrm{Cr}$ & $\mathrm{Fe}$ & $\mathrm{Ti}$ & $\mathrm{Al}$ & $\mathrm{Nb}$ & $\mathrm{Ta}$ & $\mathrm{Mo}$ & $\mathrm{Mn}$ & $\mathrm{Si}$ & $\mathrm{P}$ \\
\hline 50.3 & 19.4 & 19.6 & 0.95 & 0.43 & 5.20 & 0.11 & 3.00 & 0.16 & 0.21 & 0.010
\end{tabular}

\begin{tabular}{cccccccccc}
$\mathrm{S}$ & $\mathrm{B}$ & $\mathrm{Cu}$ & $\mathrm{C}$ & $\mathrm{Co}$ & $\mathrm{Zn}$ & $\mathrm{V}$ & $\mathrm{Mg}$ & $\mathrm{Zr}$ & $\mathrm{N}$ \\
\hline 0.001 & 0.005 & 0.05 & 0.054 & 0.26 & 0.002 & $<0.05$ & $<0.001$ & $<0.009$ & 0.0091
\end{tabular}


TABLE II

HEAT TREATMENTS

\begin{tabular}{|c|c|c|}
\hline A & As hot worked; $720 \mathrm{C} / 8 \mathrm{~h}$. F.C. to $620 \mathrm{C}$ hold for $18 \mathrm{~h}$ total. & $45 \mathrm{Rc}$ \\
\hline B & $1038 \mathrm{C} / 1 \mathrm{~h} \mathrm{AC}$ : $982 \mathrm{C} / 8 \mathrm{~h} ; 760 \mathrm{C} / 8 \mathrm{~h} ; 649 \mathrm{C} / 8$ & $43 \mathrm{Rc}$ \\
\hline $\mathrm{C}$ & $1038 \mathrm{C} / 1 \mathrm{~h} ; 871 \mathrm{C} / 8 \mathrm{~h} ; 760 \mathrm{C} / 8 \mathrm{~h} ; 649 \mathrm{C} / 8 \mathrm{~h} ;$ & $40 \mathrm{Rc}$ \\
\hline D & $\begin{array}{l}1038 \mathrm{C} / 1 \mathrm{~h} ; 720 \mathrm{C} / 10 \mathrm{~h}, \mathrm{~F} . \mathrm{C} \text {. at } 56 \mathrm{C} / \mathrm{h} \text { to } 620 \mathrm{C} \text { hold for } \\
20 \mathrm{~h} \text { total }\end{array}$ & $44 \mathrm{Rc}$ \\
\hline $\mathrm{E}$ & $\begin{array}{l}982 \mathrm{C} / 1 \mathrm{~h} ; 718 \mathrm{C} / 8 \mathrm{~h} \mathrm{~F} . \mathrm{C} . \text { at } 56 \mathrm{C} / \mathrm{h} \text { to } 621 \mathrm{C} \text { hold for } \\
18 \mathrm{~h} \text { total }\end{array}$ & \\
\hline
\end{tabular}

$\underline{\text { SCC Testing }}$

SCC tests were conducted using beam and U-bend specimens, and the SCC crack growth tests were performed using precracked wedge-loaded compact tension specimens. Beam specimens of each material, measuring $9.53 \mathrm{~cm}(3.75 \mathrm{in}) \times 1.27$ $\mathrm{cm}(0.5 \mathrm{in}) \times 0.32 \mathrm{~cm}(0.125 \mathrm{in})$ were loaded in three-point bending to $1.5 \%$ and $6.5 \%$ total outer fiber strain. U-bend specimens were fabricated by bending over a $2.54 \mathrm{~cm}$ (1 in) diameter bar. (Spring back was not allowed.) Precracked $1.27 \mathrm{~cm}$ ( 0.5 in) thick compact tension specimens were wedge-loaded to initial stress intensities of $44 \mathrm{MPa} / \mathrm{m}$. Identical sets of samples of each material were loaded into two 316 stainless steel autoclaves. One autoclave was operated with a simulated pressurized water reactor environment, as described in Table III. The other autoclave was operated with a simulated boiling water reactor chemistry, Table IV. Exposure to low temperatures was minimized by heating as rapidly as possible, and by venting the autoclaves at temperature prior to shutdown. Inspections were conducted after exposures of 528, 1528, 3028, 5028, and 6756 hours. At each inspection, the specimens were examined using a $30 \mathrm{X}$ binocular microscope. Any cracking was subsequently characterized using conventional optical metallography and scanning electron microscopy.

Microstructural Characterization

The microstructures of the various thermally treated samples were characterized by analytical electron microscopy. Electron transparent thin-foil specimens were prepared by conventional jet polishing techniques, and were examined in a Philips EM400T analytical electron microscope operated at $120 \mathrm{kV}$. The microscope was interfaced with a Link Analytical windowless EDS spectrometer and AN10/85S analyzer. Phase identification was performed using electron diffraction techniques and scanning transmission electron microscopy-energy dispersive $x$-ray spectroscopy (STEM-EDS) microanalysis. 
TABLE III

PWR ENVIRONMENT CHEMISTRY

\begin{aligned} & $\mathrm{O}_{2}<10 \mathrm{ppb} \\ & \mathrm{Li}=2 \mathrm{ppm}$ as LiOH \\ & Boric Acid $=5700 \mathrm{ppm}(1000 \mathrm{ppm} \mathrm{B}) \\ &($ This lead to $\mathrm{pH}$ of 6.5 to \\ & 7 at room temperature $) \\ &$ Dissolved $\mathrm{H}_{2}=40 \mathrm{cc} \mathrm{STP} / \mathrm{kg} \\ & \mathrm{Cl}^{-}<0.10 \mathrm{ppm} \\ & \mathrm{FI}^{-}<0.10 \mathrm{ppm} \\ &$ Conductivity $<20 \mu \mathrm{S} / \mathrm{cm} \\ &$ Flow Rate $=150 \mathrm{to} 300 \mathrm{cc} / \mathrm{h} \\ &$ Temperature $=650^{\circ} \mathrm{F}\left(343^{\circ} \mathrm{C}\right) \\ &$\hline\end{aligned}

TABLE IV

BWR ENVIRONMENT CHEMISTRY

$$
\begin{aligned}
\mathrm{O}_{2} & =200 \pm 100 \mathrm{ppb} \\
\text { Conductivity } & =0.5 \pm 0.2 \mu \mathrm{S} / \mathrm{cm} \\
\mathrm{Cl}^{-} & =0.2 \mathrm{ppm} \\
\mathrm{pH} & =5.5 \pm 0.5 @ 550^{\circ} \mathrm{F}\left(288^{\circ} \mathrm{C}\right) \\
\text { Pressure } & =1.220 \pm 10 \mathrm{psig}(8.4 \pm 0.07 \mathrm{MPa}) \\
\text { Temperature } & =550 \pm 10^{\circ} \mathrm{F}\left(288 \pm 5^{\circ} \mathrm{C}\right) \\
\text { Flow Rate } & =0.5 \mathrm{gal} / \mathrm{h}(1.9 \mathrm{~L} / \mathrm{h})
\end{aligned}
$$

\section{RESULTS}

$\underline{\mathrm{SCC}}$

Crack initiation and growth were observed in beam specimens exposed to both environments. The initiation and growth data are presented in Tables $V$ and VI. respectively. All of the crack growth and remaining stress intensity values were calculated from the crack length measurements taken from the crack faces after fracture at $-196^{\circ} \mathrm{C}$. Significant bowing of the crack front was observed, with the central region having the longest crack length. In order to provide a meaningful measure of the crack lengths, a five-point average of the crack length was used. In all specimens, the SCC morphology was found to be completely intergranular. 
TABLE $V$

CRACK INITIATION RESULTS FOR ALLOY 718 IN BWR ENVIRONMENT

\begin{tabular}{|c|c|c|c|}
\hline \multirow{2}{*}{$\begin{array}{l}\text { Specimen } \\
\text { Condition }\end{array}$} & \multicolumn{2}{|c|}{ Bent Beam } & \multirow[b]{2}{*}{ U-Bends } \\
\hline & $1.5 \%$ Strain & $6.5 \%$ Strain & \\
\hline $\begin{array}{l}A \\
B \\
C \\
D \\
E\end{array}$ & $\begin{array}{l}\checkmark \\
v \\
v \\
v \\
v\end{array}$ & $\begin{array}{l}\checkmark \\
\checkmark \\
v \\
v \\
v\end{array}$ & $\begin{array}{c}\checkmark \\
6756 \\
\checkmark \\
\checkmark \\
\checkmark\end{array}$ \\
\hline
\end{tabular}

CRACK INITIATION RESULTS FOR ALLOY 718 IN PWR ENVIRONMENT

$\begin{array}{cccc}\text { A } & \checkmark & \checkmark & \checkmark \\ \text { B } & \checkmark & 3028 & 6756 \\ \text { C } & \checkmark & 6756 & \checkmark \\ \text { D } & \checkmark & \checkmark & \checkmark \\ \text { E } & \checkmark & \checkmark & \checkmark\end{array}$

$\checkmark=$ no cracks at $6756 \mathrm{~h}$

Number $=$ time to crack observation in hours

TABLE VI

CRACK GROWTH DATA FROM FRACTURED ALLOY 718 SPECIMENS AFTER 6756 HOURS OF EXPOSURE

\begin{tabular}{|c|c|c|c|c|}
\hline \multirow[b]{2}{*}{$\begin{array}{l}\text { Specimen } \\
\text { Condition }\end{array}$} & \multicolumn{2}{|c|}{ PWR } & \multicolumn{2}{|c|}{ BWR } \\
\hline & $\begin{array}{c}\mathrm{da} / \mathrm{dt} \\
\left(\mathrm{mm} / \mathrm{h} \times 10^{-4}\right.\end{array}$ & $\frac{\mathrm{K}_{\mathrm{IF}}}{(\mathrm{MPa} \mathrm{m})}$ & $\begin{array}{c}\mathrm{da} / \mathrm{dt} \\
\left(\mathrm{mm} / \mathrm{h} \times 10^{-4}\right)\end{array}$ & $\frac{\mathrm{K}_{\mathrm{IF}}}{(\mathrm{MPa} \mathrm{m})}$ \\
\hline $\begin{array}{l}A \\
B \\
C \\
D\end{array}$ & $\begin{array}{r}5.33 \\
10.59 \\
9.30 \\
4.90\end{array}$ & $\begin{array}{l}36.8 \\
28.1 \\
30.1 \\
37.6\end{array}$ & $\begin{array}{l}2.24 \\
7.11 \\
7.87 \\
3.78\end{array}$ & $\begin{array}{l}43.3 \\
33.6 \\
32.3 \\
39.8\end{array}$ \\
\hline $\begin{array}{l}E \\
E\end{array}$ & $\begin{array}{l}14.00 \\
15.37\end{array}$ & $\begin{array}{l}20.4 \\
18.2\end{array}$ & $\begin{array}{r}11.00 \\
8.41\end{array}$ & $\begin{array}{l}24.8 \\
28.6\end{array}$ \\
\hline
\end{tabular}

\section{Microstructure}

The different microstructures that developed during the heat treatments were characterized by analytical electron microscopy. The specific microstructural features observed for each material were:

Material A - Fine $\gamma^{\prime \prime}$ and $\gamma^{\prime}$ precipitates, approximately $10-30 \mathrm{~nm}$ in size, were observed throughout the matrix. Slightly coarser $\gamma^{\prime \prime}$ precipitates decorated dislocations in the matrix. Although $\boldsymbol{\gamma}^{\mathrm{m}}$ was detected at numerous grain boundaries, 
discrete intergranular $\delta$ precipitates were also present. The presence of $\delta$ at grain boundaries was reflected in the formation of narrow $(\sim 50 \mathrm{~nm})$ zones free of $\gamma$ ". The $\delta$ formed as thin $(10-20 \mathrm{~nm})$ precipitates generally 0.2 to 0.5 micron in length. Some representative microstructures are presented in Figure 1.

Material B - This material was characterized by the presence of fine intragranular $\gamma^{\prime \prime}$ precipitates, approximately $10-40 \mathrm{~nm}$ in length. Some fine $\gamma^{*}$ was also detected throughout the matrix. Most grain boundaries were decorated with slightly coarser $\gamma^{\prime \prime}$ precipitates. Typical structures are presented in Figures 2 and 3 . Other coarse precipitates such as MC carbides and globular Laves phase were occasionally observed in this material. These phases were most probably present prior to the solution anneal and did not dissolve during the solution anneal or subsequent aging treatments. Their presence did not appear to have any effect on the subsequent precipitation of $\gamma^{\prime \prime}$ and $\gamma^{\prime}$ since no precipitate free zones were observed in the vicinity of these features.

Material C - A complex microstructure was produced by this multi-step thermal treatment. Coarse $\gamma^{\prime \prime}$ precipitates, about 0.3 micron in length, were observed throughout the matrix. In addition, fine $\gamma^{\prime \prime}$ and $\gamma^{\prime}$ were present in the $\gamma$ matrix. Detailed examination of the primary $\gamma^{\prime \prime}$ revealed the presence of associated narrow regions that were free of secondary $\gamma^{\prime \prime}$; these zones are evident in the transmission electron micrograph of Figure 4. Also, preferential precipitation of $\delta$ was observed at grain boundaries. In a manner similar to the precipitation of primary $\gamma^{\prime \prime}$, the precipitation of $\delta$ was accompanied by the formation of a primary $\gamma^{\prime \prime}$ precipitate free zone at the grain boundaries. The zone was approximately 1 micron in width. The grain boundaries which contained $\delta$ exhibited a duplex precipitate free zone: a broad zone from which primary $\gamma^{m}$ was excluded, and a narrower zone closer to the $\delta$ from which secondary $\gamma^{\prime \prime}$ was excluded. The double zone structure is shown in Figure 5.

Material D - This material was characterized by the presence of a uniform distribution of fine $\gamma^{\prime \prime}$ and some fine $\gamma^{\circ}$ precipitates. These precipitates were approximately $10-20 \mathrm{~nm}$ in size as shown in Figure 6. No precipitates other than $\gamma^{\prime \prime}$ were observed at grain boundaries. A few coarse Laves and MC precipitates were occasionally detected, Figure 7.

Material E - TEM examination of this material revealed extensive $\gamma^{\prime \prime}$ and $\gamma^{\prime}$ precipitation throughout the matrix. The fine size $(10-20 \mathrm{~nm})$ of these precipitates is evident in the complementary bright and dark-field transmission electron micrographs of Figure 8 . Slightly coarser precipitates were observed to decorate dislocations. The dominant grain boundary phase was Laves phase. Coarse globular particles of Laves phase $0.5-2$ microns in length were detected along most grain boundaries. Figure 9 . In addition to Laves phase, discrete $\delta$ precipitates were present along some grain boundaries. Both plate/needle-like and small globular morphologies were observed. The precipitation of $\delta$ resulted in a localized depletion of $\mathrm{Nb}$ in the matrix, which was reflected in the development of narrow $\gamma^{\prime \prime}$ precipitate-free zones. The typical microstructure is presented in Figure 10.

The various microstructural features which characterize the individual thermal treatments are summarized in Table VII. 
TABLE VII

SUMMARY OF MICROSTRUCTURAL FEATURES

IN THERMALLY TREATED ALLOY 718 SAMPLES

\begin{tabular}{|c|c|c|c|c|c|c|c|}
\hline Material & $\begin{array}{l}\text { Additional } \\
\text { Aging } \\
\text { Step }\end{array}$ & Laves & $\delta$ & $\gamma_{p}{ }^{n}$ & $\gamma_{s}{ }^{\prime \prime}$ & $\gamma^{\prime}$ & $\gamma^{\prime \prime} \mathrm{p} f z$ \\
\hline$A$ & & Few & No & No & Yes & Yes & $\begin{array}{l}\text { Yes - } \\
\text { narrow }\end{array}$ \\
\hline B & $\left(982^{\circ} \mathrm{C}\right)$ & $\begin{array}{l}\text { Yes/Ghost } \\
\text { Boundaries }\end{array}$ & No & No & Yes & Yes & No \\
\hline C & $\left(871^{\circ} \mathrm{C}\right)$ & $\begin{array}{l}\text { Yes/Ghost } \\
\text { Boundaries }\end{array}$ & Yes & Yes & Yes & Yes & $\begin{array}{l}\text { Yes - } \\
\text { double zones }\end{array}$ \\
\hline D & & Few & No & No & Yes & Yes & No \\
\hline$E$ & $\left(982^{\circ} \mathrm{C}\right)$ & $\begin{array}{l}\text { Yes - } \\
\quad \text { Intergranular }\end{array}$ & Few & No & Yes & Yes & $\begin{array}{l}\text { Yes - } \\
\text { narrow }\end{array}$ \\
\hline
\end{tabular}

\section{DISCUSSION}

Significant proportions of Laves phase are present in Material $E$, which was the starting material for heat treatments B, C, and D. In Materials B, C, and D, Laves phase is located both at grain boundaries and within the matrix denoting a prior position of the grain boundary. TEM examination revealed that Materials $A$ and $D$ contained a notably reduced amount of Laves phase. The structures indicate that the Laves phase was not completely dissolved by the $1038^{\circ} \mathrm{C}$ solution temperature and that aging may have only affected the amount present. Blocky Laves phase and $M C$ carbides were always present and varied from TEM foil to TEM foil, indicating segregation in the alloy. The presence of primary $\gamma^{\prime \prime}$ (Material C), secondary $\gamma^{\prime \prime}$ and $\gamma^{\prime}$ (Materials A,B,C,D, and E) were the result of the intermediate aging steps. Aging at $871^{\circ} \mathrm{C}$ promoted the formation of primary $\gamma^{\prime \prime}$. whereas the $760^{\circ} \mathrm{C}$ and $720^{\circ} \mathrm{C}$ heat treatments resulted in the precipitation of fine $\gamma "$ and $\gamma^{\prime}$. The precipitation of $\delta$ was significant in Material C, being developed during the $871^{\circ} \mathrm{C}$ age. A small amount of $\delta$ was detected at grain boundaries in Materials $A$ and $D$.

The various aging steps of the heat treatments studied were associated with the precipitation of both grain boundary and matrix phases, as summarized in Table VII. All materials were characterized by the presence of fine intragranular $\gamma^{\prime \prime}$ and $\gamma^{\prime}$ precipitates. In addition, Material C contained coarse $\gamma^{\prime \prime}$ (primary $\gamma^{\prime \prime}$ ) and $\delta$ precipitates. A small amount of $\delta$ was observed at a few grain boundaries in materials $A$ and $E$. No $\delta$ was detected in Materials B or D. Zones near $\delta$ which were free of $\gamma^{\prime \prime}$ precipitates were observed in Materials A, C, and E. Material C exhibited the most pronounced precipitate free zones near both intra- and intergranular $\delta$. 
The SCC initiation data, Table $V$, show that the alloy is, in general, resistant to crack initiation in both BWR and PWR environments. Only one $\mathrm{U}$-bend specimen of material $B$ was observed to crack in the BWR environment, although material $E$ cracked after longer exposures to this environment [3]. Materials B and C were susceptible to crack initiation in the PWR environment whereas $A$ and $D$ were resistant to initiation in either environment. Crack growth, however, was observed in all material conditions in both environments, as shown in Table VI. The lowest crack growth rates for both BWR and PWR environments were associated with Materials $A$ and $D$.

All materials except $B$ exhibited the good resistance to SCC initiation in the BWR environment. The crack growth data showed that Materials $A$ and $D$ had the lowest propagation rates, whereas significantly higher growth rates were observed for Materials B.C, and E. Although Material E exhibited the highest crack growth rate, it had displayed good resistance to crack initiation. The common microstructural feature to Materials B.C, and E was the presence of a significant proportion of Laves phase. These materials had also been subjected to an intermediate aging step at either $982^{\circ} \mathrm{C}$ or $871^{\circ} \mathrm{C}$.

The SCC data for the PWR environment was similar to that observed for the BWR tests. Material B exhibited the poorest resistance to crack initiation in the PWR environment. Crack initiation was also observed in Material C. No cracking was detected for Materials A, D, or E. Crack propagation rates for Materials A and D were considerably lower than the rates for Materials $B, C$, and $E$, with Material $E$ exhibiting the highest growth rate. Materials $A$ and $D$ contained a reduced amount of Laves phase as compared with Materials B,C, and E. None of the other precipitates observed in the microstructure demonstrated the same correlation with SCC performance.

The microstructural investigation has shown that a small amount of Laves phase is still present after the "good" heat treatments. It is possible that a higher solution annealing temperature could eliminate this phase and result in an improved material. However, this higher annealing temperature would promote significant grain growth which could lead to a reduction in other properties such as fatigue strength. This approach will require further investigation and evaluation for nuclear applications. Although there is a strong correlation between the presence of Laves phase and SCC susceptibility, the physical metallurgy of this alloy is complex and other factors may influence the material performance. Segregation of various solute species to the grain boundaries during annealing and/or aging may also be a factor in controlling the SCC behavior. A detailed study is needed to optimize the heat treatment and microstructure in the absence of Laves phase in order to improve resistance to SCC. 


\section{CONCLUSIONS}

1. Alloy 718 is resistant to stress corrosion crack initiation in light water reactor environments, but growth is possible from cracks associated with small defects in the material.

2. Heat treatments can be used to improve the resistance to SCC initiation and propagation.

3. There is a strong correlation between the presence of Laves phase and susceptibility to SCC initiation and growth.

\section{ACKNOWLEDGEMENTS}

The experimental assistance of J.J. Haugh is greatly appreciated. The authors thank T.R. Mager of Westinghouse Electric. Corp. for helpful discussions. This research was supported by the Electric Power Research Institute, Dr. J.L. Nelson. Program Manager.

\section{REFERENCES}

1. A.R. Mcllree, "Degradation of High Strength Austenitic Alloys X-750, 718 and A-286 in Nuclear Power Systems". Environmental Degradation of Materials in Nuclear Power Systems--Water Reactors. (Houston,TX: NACE, 1984) 838-852.

2. P. Berge, "Experience with Alloy X-750 Cracking in PWRs." (Paper presented at E.P.R.I. Workshop on Advanced High Strength Materials for LWR Internal Applications, Clearwater, FL. March 1986).

3. I.L.W. Wilson, "SCC Behavior of Alloys 718 and -286." (Paper presented at E.P.R.I. Workshop on Advanced High Strength Materials for LWR Internal Applications, Clearwater, FL, March 1986).

4. M. Tsubota et al., "SCC Susceptibility of Inconel 718." (Paper presented at E.P.R.I. Workshop on Advanced High Strength Materials for LWR Internal Applications, Clearwater, FL, March 1986).

5. T. Yonezawa et al., "Effect of Heat Treatment on Stress Corrosion Cracking Resistance of High Nickel Alloys in High Temperature Water". Environmental Degradation of Materials in Nuclear Power Systems--Water Reactors. (Houston, TX: NACE, 1984) 345-365.

6. R. A. Ballinger, MIT, unpublished data on EPRI project, RP1166-4, 1986.

7. M. G. Burke and M. K. Miller, "APFIM/TEM Characterization of Precipitation in Alloy 718," J. de Physique 50:C8 (1989) 395-400.

8. M. G. Burke and M. K. Miller, "Precipitation in Alloy 718: A Combined AEM and APFIM Investigation." This Proceedings. 

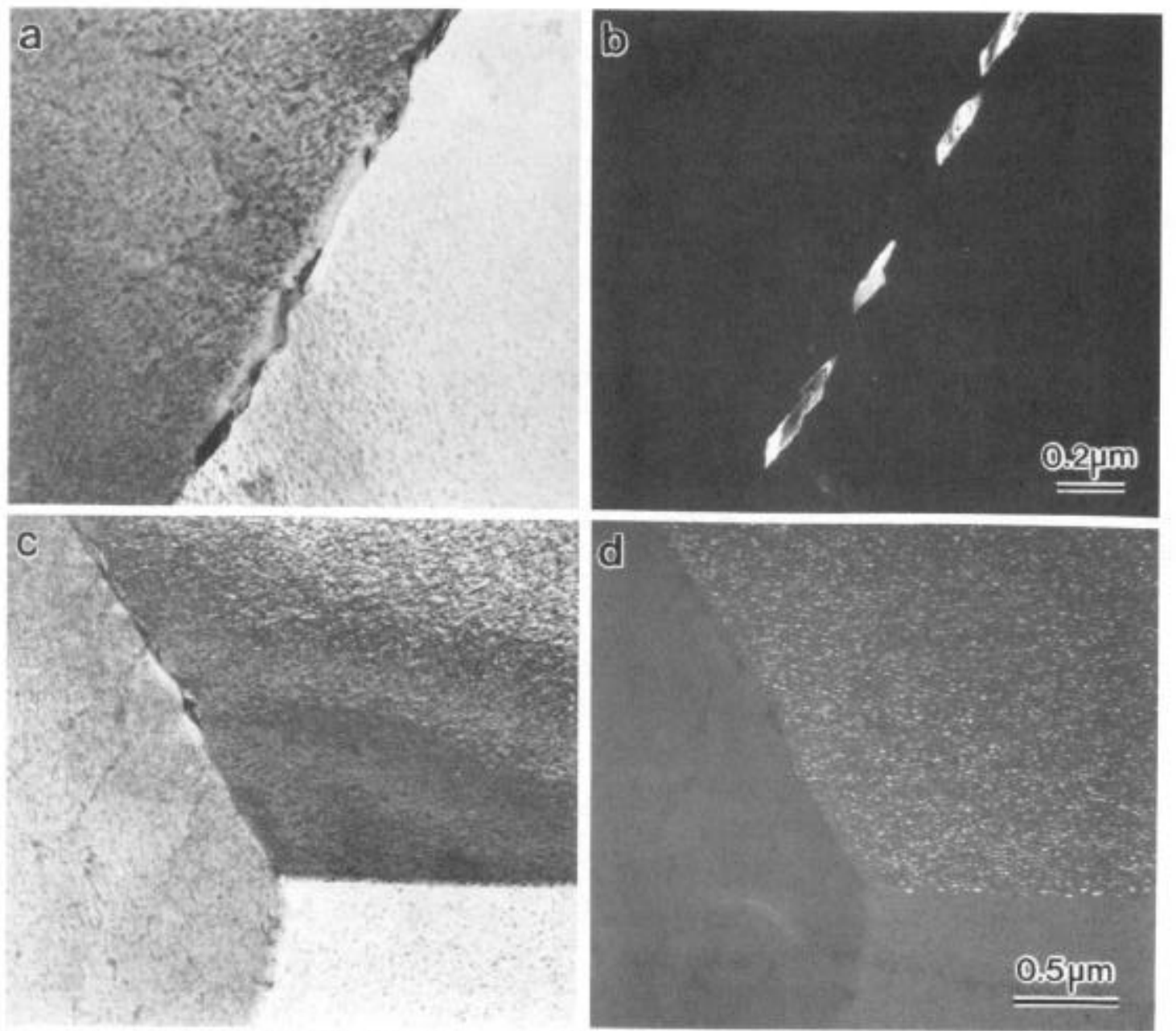

Figure 1. Bright and dark field transmission electron micrographs of Material A which show intergranular $\delta(a, b)$ and fine $\gamma^{\prime \prime}$ precipitates (c,d).

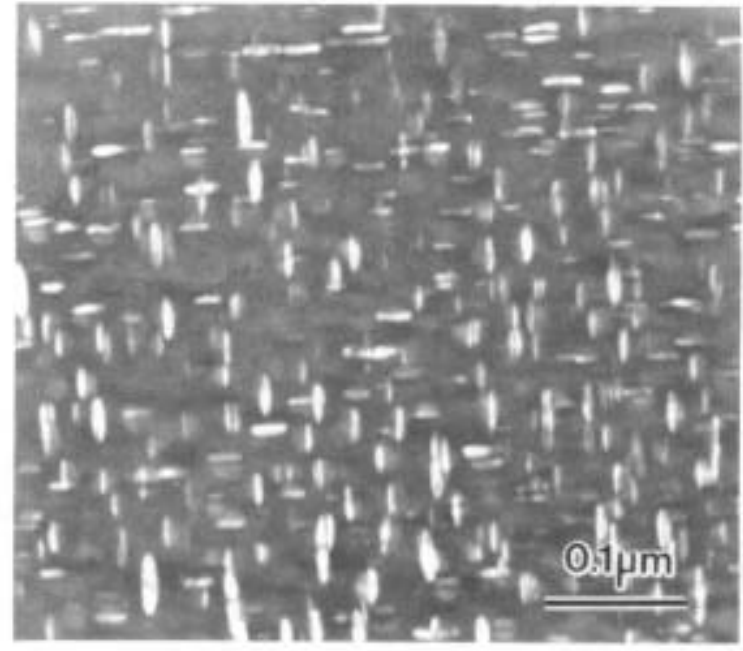

Figure 2. Dark field micrograph of fine $\gamma^{\prime \prime}$ precipitates observed in Material B.

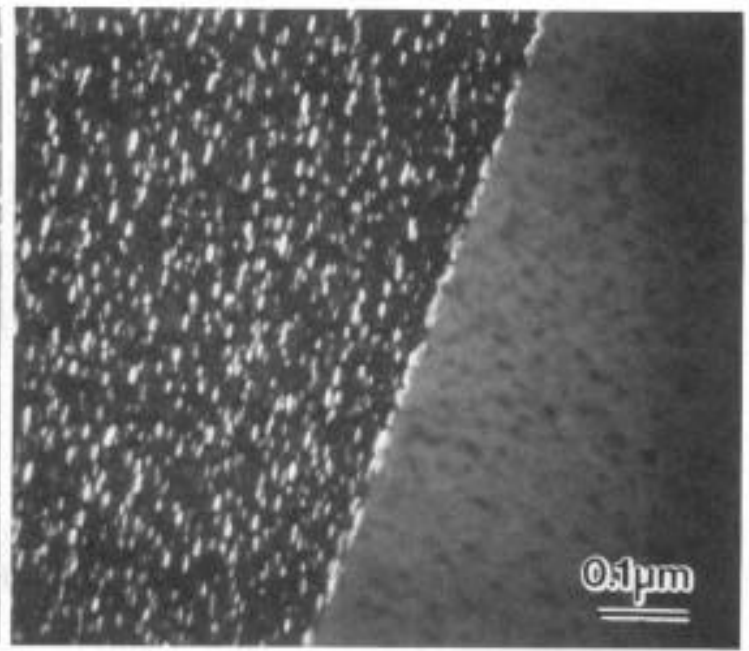

Figure 3. Inter- and intragranular $\gamma^{\prime \prime}$ precipitates in Material B. 

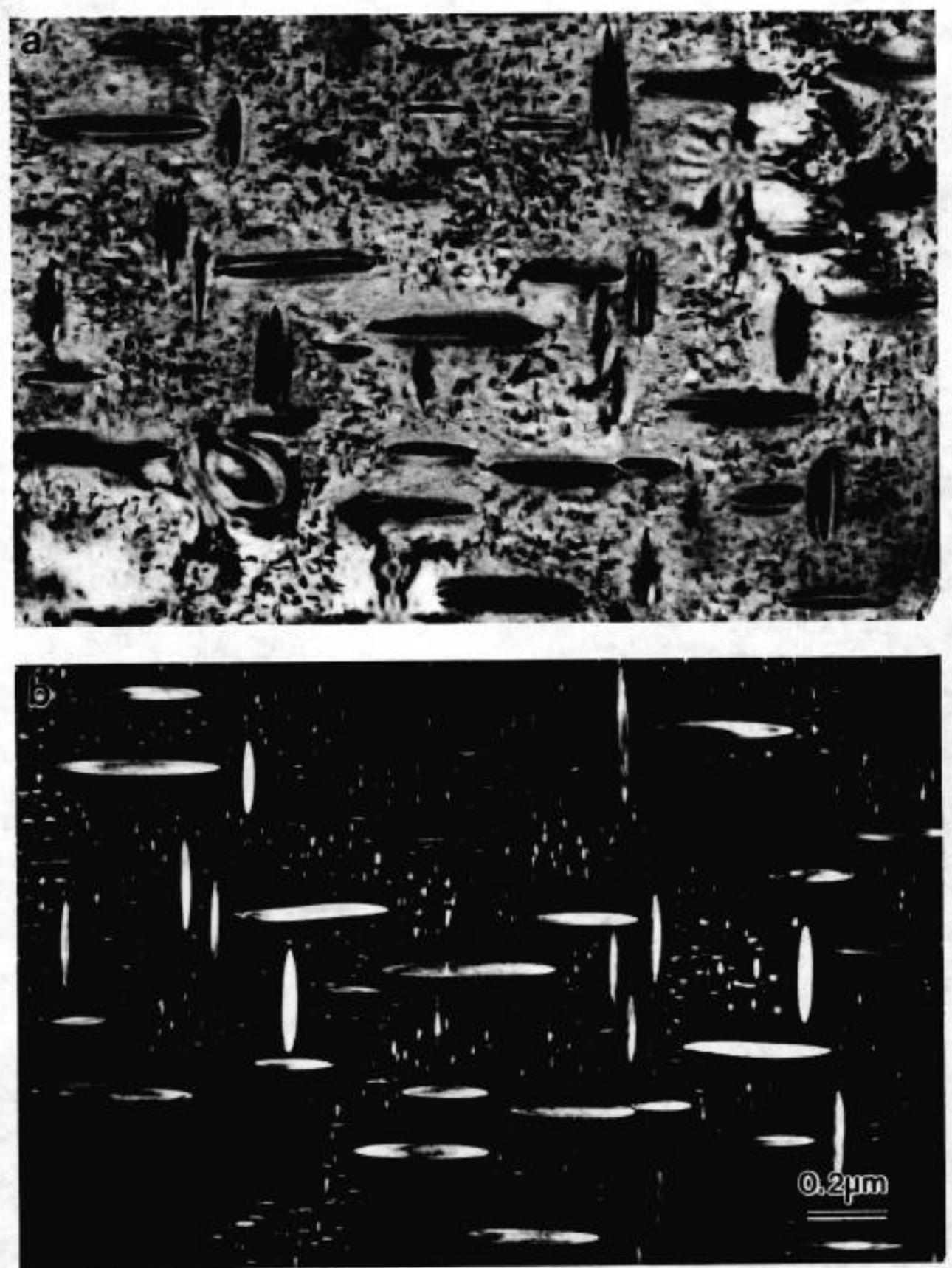

Figure 4. (a) Bright and (b) dark field transmission electron micrographs of primary and secondary $\boldsymbol{\gamma}^{\prime \prime}$ and $\boldsymbol{\gamma}^{*}$ precipitates present in Material C. Two of the three $\langle 100\rangle$ variants of $\gamma^{\prime \prime}$ are visible. 

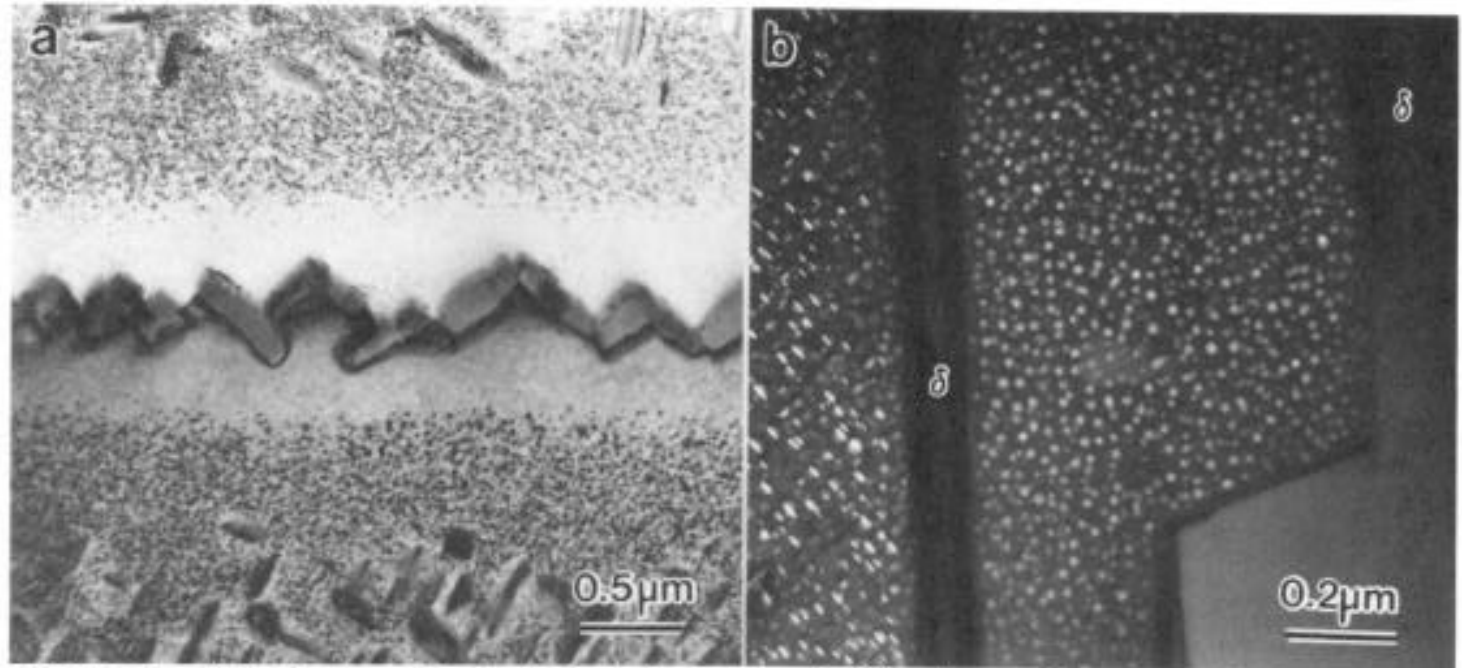

Figure 5. (a) Duplex $\gamma^{\prime \prime}$ precipitate free zone (pfz) observed in the vicinity of intergranular $\delta$ in Material C. (b) Dark field micrograph of $\gamma^{*}$ formed within the $\gamma^{\prime \prime}$ pfz between two $\delta$ precipitates.

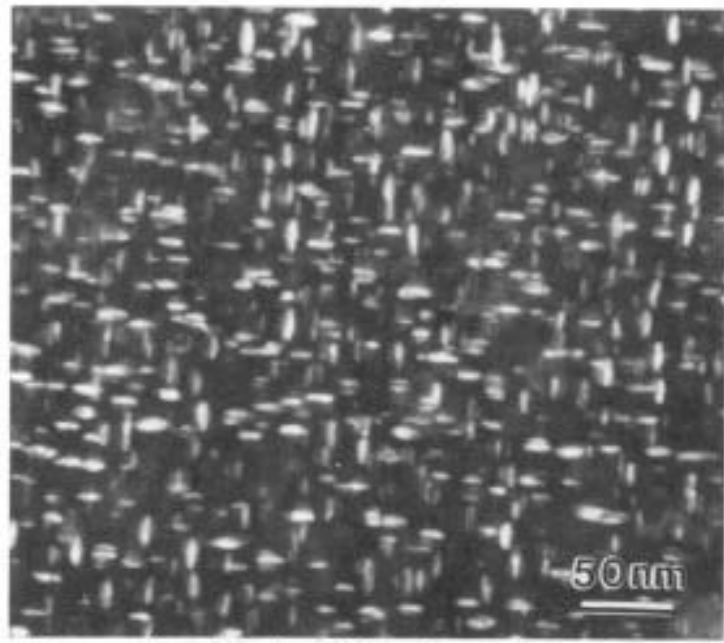

Figure 6. Dark field micrograph of $\gamma^{\prime \prime}$ and $\gamma^{*}$ in Material D.

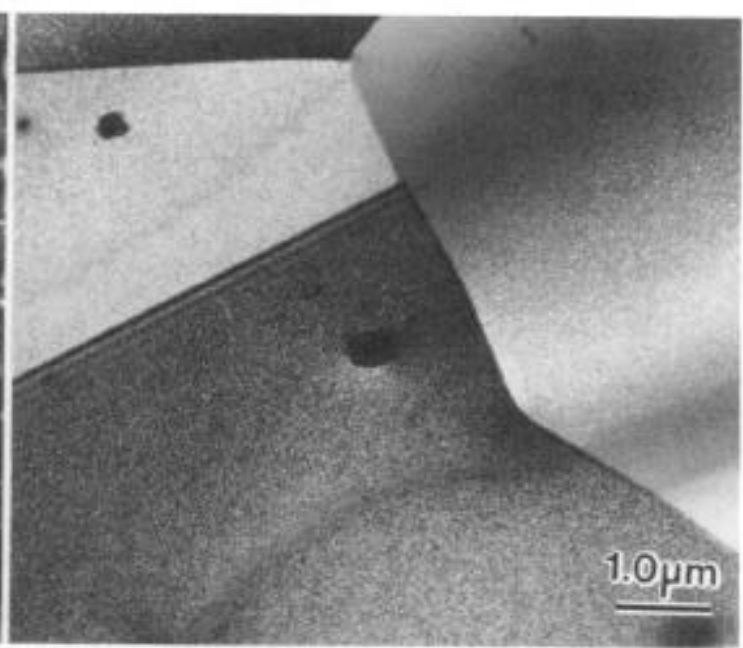

Figure 7. A few isolated second phase particles (MC and Laves phase) observed in Material D.

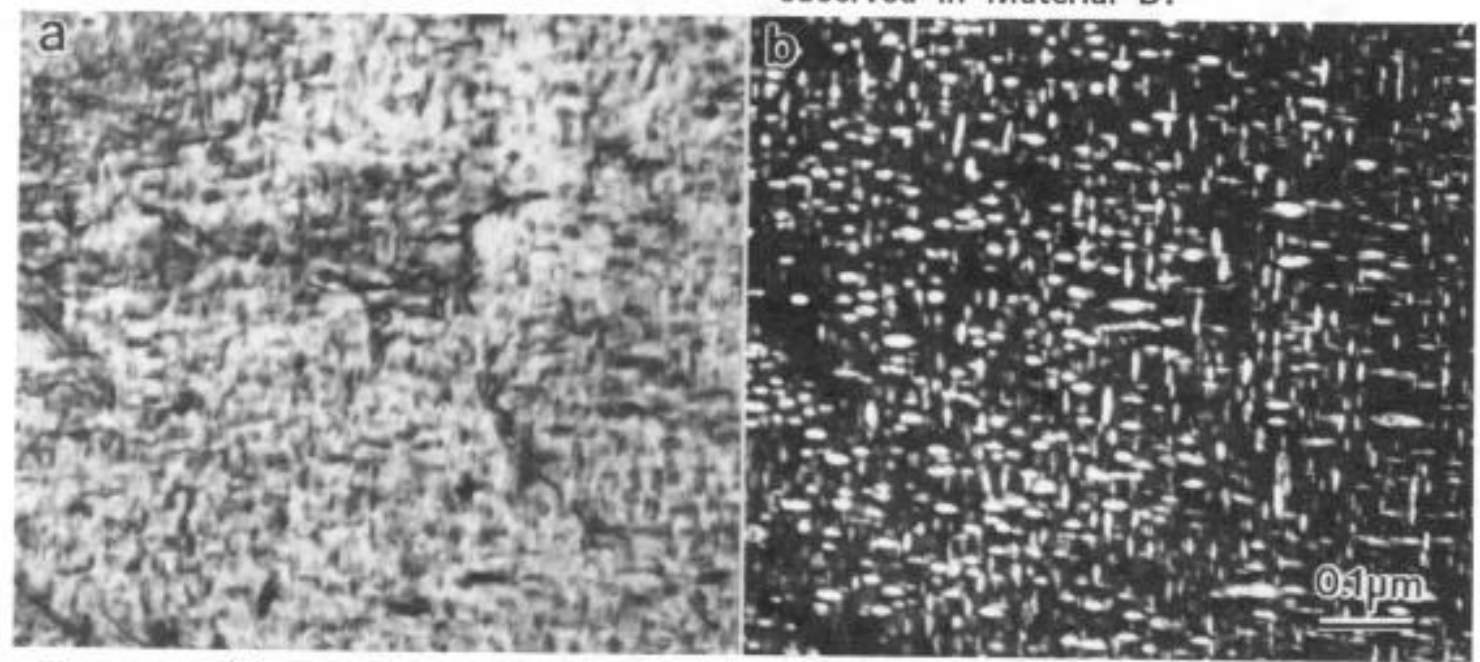

Figure 8. (a) Bright and (b) dark field micrographs of fine $\gamma^{\prime \prime}$ and $\gamma^{\prime}$ in Material $E$. 


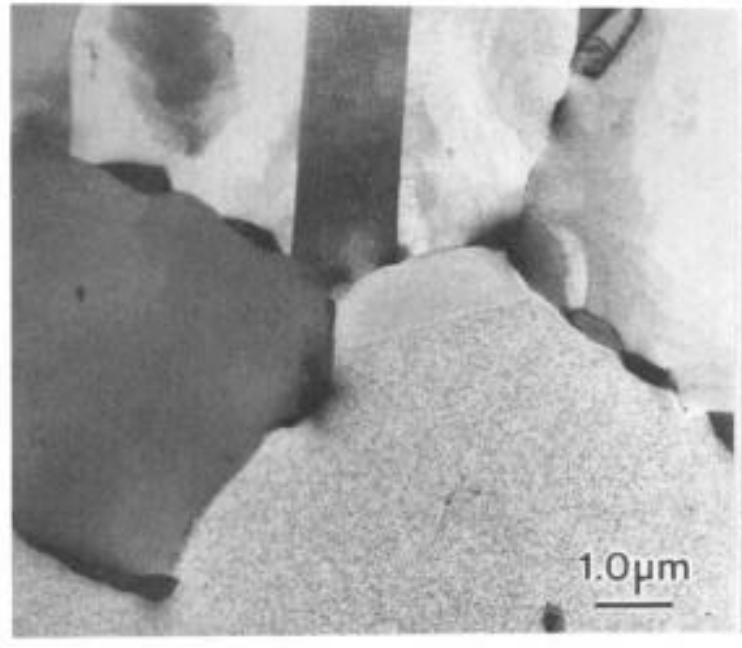

Figure 9. Intergranular Laves phase precipitates present in Material E.

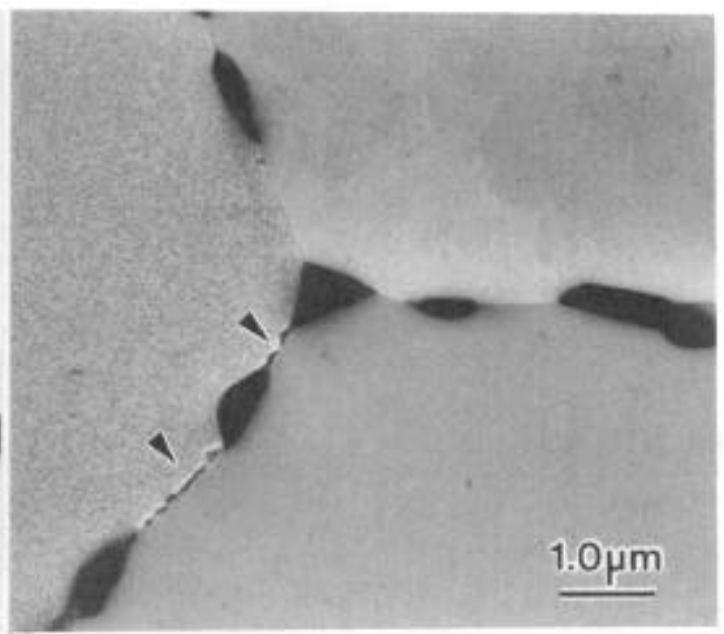

Figure 10. Narrow $\gamma^{\prime \prime}$ pfz (arrowed) associated with the precipitation of $\delta$ along grain boundaries in Material E.

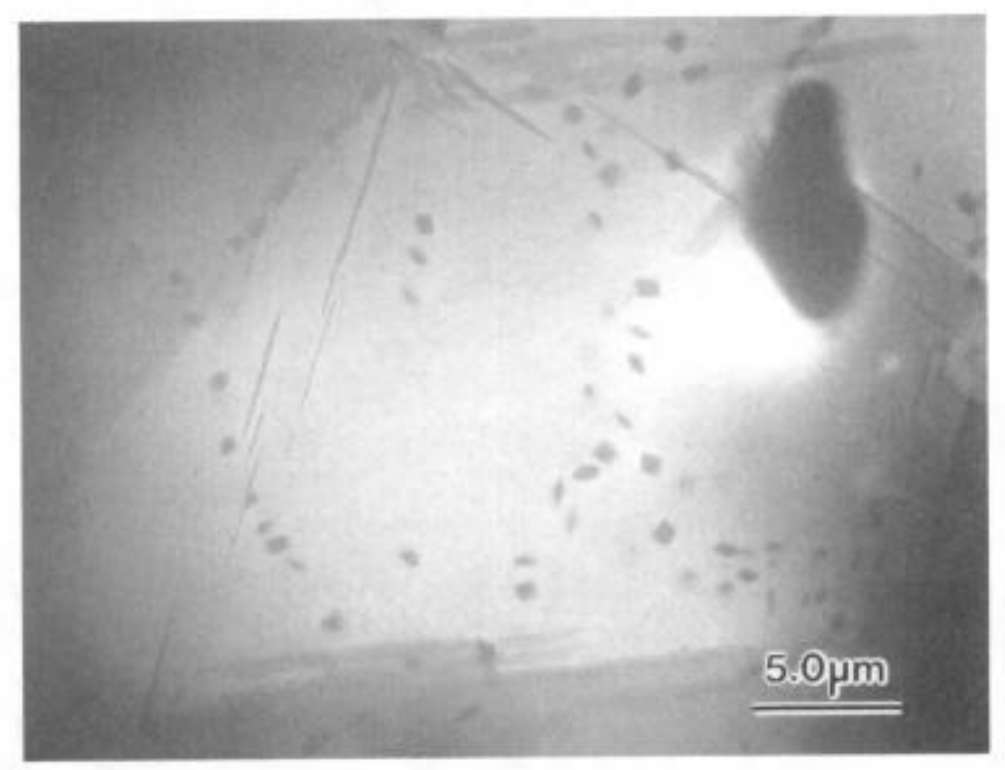

Figure 11. STEM image of Laves phase precipitates in Material C which delineate the original position of the grain boundaries prior to the solution anneal. 